\title{
Effect of Oxaliplatin on Voltage-Gated Sodium Channels in Peripheral Neuropathic Pain
}

\author{
Woojin Kim \\ Department of Physiology, College of Korean Medicine, Kyung Hee University, Seoul 02453, Korea; \\ wjkim@khu.ac.kr; Tel.: +82-2-961-0334
}

Received: 6 May 2020; Accepted: 6 June 2020; Published: 9 June 2020

\begin{abstract}
Oxaliplatin is a chemotherapeutic drug widely used to treat various types of tumors. However, it can induce a serious peripheral neuropathy characterized by cold and mechanical allodynia that can even disrupt the treatment schedule. Since the approval of the agent, many laboratories, including ours, have focused their research on finding a drug or method to decrease this side effect. However, to date no drug that can effectively reduce the pain without causing any adverse events has been developed, and the mechanism of the action of oxaliplatin is not clearly understood. On the dorsal root ganglia (DRG) sensory neurons, oxaliplatin is reported to modify their functions, such as the propagation of the action potential and induction of neuropathic pain. Voltage-gated sodium channels in the DRG neurons are important, as they play a major role in the excitability of the cell by initiating the action potential. Thus, in this small review, eight studies that investigated the effect of oxaliplatin on sodium channels of peripheral neurons have been included. Its effects on the duration of the action potential, peak of the sodium current, voltage-response relationship, inactivation current, and sensitivity to tetrodotoxin (TTX) are discussed.
\end{abstract}

Keywords: allodynia; oxaliplatin; peripheral neuropathic pain; voltage-gated sodium channel

\section{Introduction}

Oxaliplatin is a third-generation platinum-based chemotherapeutic drug that is widely used to treat various types of cancer, such as breast, colorectal, and lung cancers [1]. Although it is an effective drug as it does not induce significant ototoxicity and nephrotoxicity like other platinum derivatives, it has a serious side effect, which is characterized by paresthesia and dysesthesia of hands and feet, which can often lead to the discontinuation of therapy [2]. Hence, understanding the mechanism of action and finding an effective treatment for oxaliplatin-induced neuropathic pain are critical issues for treatment, and for the patients' quality of life.

Although the mechanism underlying oxaliplatin-induced neuropathic pain remains unclear, mechanistic studies have reported various pathways. Sodium, potassium, and calcium ion channels and different types of transient receptor potential family (TRPA1, TRPM8, and TRPV1) were shown to be involved, as their function altered after oxaliplatin injection [3-7]. In other studies, increased activity of spinal glia cells and pro-inflammatory and neuroexcitatory cytokines (tumor necrosis factor alpha and interleukin-1beta) in the dorsal horn of the spinal cord were associated with oxaliplatin [8,9]. Furthermore, environmental changes owing to oxaliplatin administration, such as toxic effects on mitochondria [10] and $\mathrm{pH}$ acidification [11] in the dorsal root ganglia (DRG) sensory neurons have also been suggested as the cause of allodynia and hyperexcitability.

For several years, we have focused on finding an effective method to decrease this pain. Using an animal model of oxaliplatin-induced neuropathic pain, which showed similar symptoms to patients, such as cold and mechanical allodynia [12-14], we have reported that various treatments with 
well-known drugs, such as morphine [13] and duloxetine [15], and alternative methods [16], such as using acupuncture [17] and bee venom [13,18,19], can significantly attenuate allodynia.

Furthermore, by using in vivo spinal cord extracellular recording methods, we demonstrated that the activities of wide dynamic range (WDR) neurons, which are present in the spinal dorsal horn and encode the information received from both the innocuous and noxious signs that transmit peripheral neurons [20], are highly upregulated after oxaliplatin treatment compared to that after vehicle injection in rats $[15,16,18]$. These results let us focus on the role of peripheral sensory neurons in oxaliplatin-induced neuropathic pain [21]. The function of DRG sensory neurons, such as conduction velocity, was affected after administration of the chemotherapeutic agent. However, the number of cells remained unchanged, as did central and motor nerve conduction, suggesting that the agent mostly affects the function of the sensory neurons [21].

DRG sensory neurons play a major role in pain sensation, and their excitability is closely related to the propagation of action potentials, which transmit noxious information to the central nervous system [22]. Oxaliplatin is known to induce an immediate effect on the axonal excitability rather than structural changes, suggesting that ion channels in the DRG neurons may be involved [23]. Indeed, abnormalities in the functions of potassium and calcium ion channels were reported as the expression of pro-excitatory channels (hyperpolarization-activated channels) [24] and calcium ion influx were significantly increased following oxaliplatin injection, respectively. However, as the membrane potential of a neuron depends mostly on multiple isoforms of a voltage-gated sodium channel and the function of the sodium channels in primary DRG neurons can determine the occurrence and development of neuropathic pain, sodium channels may play a key role in oxaliplatin-induced neuropathic pain $[25,26]$. Moreover, administration of sodium channel blockers was reported to be effective against oxaliplatin-induced neuropathic pain in humans [27,28] and animals [29-31], suggesting that concentrating on the voltage-gated sodium channel may be an effective treatment approach.

Since the study published by Adelsberger et al. [31], seven more studies have investigated the effect of oxaliplatin on voltage-gated sodium channels, during the past 20 years. Thus, in this review, we included all eight studies. Clinical trials were excluded, and in vitro and in vivo studies conducted with animals were included. Animal species and nerves investigated all differed from paper to paper. Three used rats and the other three studies used mice. In addition, frogs, cockroaches, and human nerves were also analyzed in other studies.

Considering the importance of the peripheral sensory neurons and voltage-gated sodium channels in the development and maintenance of neuropathic pain, it appeared to be important to combine all studies published during the past 20 years, and report on them for a better understanding of the action of oxaliplatin and the development of an effective drug (Table 1).

\section{Effect of Oxaliplatin on Peripheral Nerve Fibers}

\subsection{Oxaliplatin Mostly Affects Myelinated A-Fibers, but Not Unmyelinated C-Fibers}

Adelsberger et al. [31] conducted an experiment on the sural, peroneal, and vagal nerves of adult rats, by evoking a stimulus of $100 \mathrm{~V}$ for $15 \mu$ s in rat sural nerves. They demonstrated that the A-fiber compound action potential (CAP) increased significantly $(218 \pm 68 \%, n=7)$. In contrast, the C-fiber CAP did not change significantly ( $36 \pm 29 \%, n=7$ ) after $45 \mathrm{~min}$ of $250 \mu \mathrm{M}$ oxaliplatin treatment, showing that oxaliplatin mostly affects A rather than C-fibers. This change in A-fiber was completely blocked by $1 \mathrm{mM}$ of a sodium channel blocker, carbamazepine. Following Adelsberger et al., Sittl et al. [32] also reported that oxaliplatin affected only myelinated A-fibers but not $C$-fibers. An electrical stimulation in the human nerve fascicle (from five male patients, $57 \pm 9$ years of age) bathed in $100 \mu \mathrm{M}$ of oxaliplatin for $90 \mathrm{~min}$ induced after-potentials in the A but not C-fiber CAP. In addition, in the sural nerves of wild-type mice, the stimulus evoked repetitive action potential discharge only in myelinated fibers, and action potentials increased upon cooling the media to $20^{\circ} \mathrm{C}$. 


\subsection{Oxaliplatin Increases the Length of the Action Potential}

By stimulating the rat sural nerve with twin pulse action potentials, Adelsberger et al. [31] reported that $250 \mu \mathrm{M}$ of oxaliplatin application increased both the amplitude and duration of action potentials. In addition, the time needed for an action potential to reach the baseline increased dramatically after $45 \mathrm{~min}$ of chemotherapeutic drug application, from $500 \mu$ s to $10 \mathrm{~ms}$. These effects were induced by lengthening the refractory period. Grolleau et al. [33] also demonstrated that $500 \mu \mathrm{M}$ of intracellularly-applied oxaliplatin reduced the spike amplitude by $19.4 \%$. However, it increased the action potential duration while reducing both the depolarizing phase and post-hyperpolarization. In their experiment, action potentials were evoked by $50 \mathrm{~ms}$ of $0.8 \mathrm{nA}$ depolarizing current-pulse stimulation in cockroach dorsal unpaired median (DUM) neurons. However, with their experiments conducted on the myelinated frog neurons, Benoit et al. [34] suggested that oxaliplatin may decrease the duration of action potentials, as in their experiments, the voltage-dependence of sodium channel inactivation moved towards negative. Although Alberti et al. [35] did not mention the duration of the action potential, they showed that intravenous administration of oxaliplatin decreased the refractory period compared to the control (control: 0.365 vs. oxaliplatin: $0.276 \mathrm{~ms}$, respectively, $P=0.02$ ), suggesting that the length of the action potential may have shortened.

\section{Oxaliplatin Modifies Activities of Voltage-Gated Sodium Channels}

\subsection{Oxaliplatin Decreases the Peak of the Sodium Current}

In their experiment, Adelsberger et al. [31] reported that $250 \mu \mathrm{M}$ of oxaliplatin decreased the maximal amplitude of the sodium current to $0.65 \pm 0.23$ in 13 out of 18 cells tested. In DUM neurons, Grolleau et al. [33] also reported that $20 \mathrm{~min}$ extracellular application of $100 \mu \mathrm{M}$ of oxaliplatin induced a slight reduction in the maximum peak sodium current (16.7 $\pm 5.8 \%$ of control). In contrast, the intracellular treatment at the same dose and time inhibited the current highly $(52.8 \pm 3.3 \%$ of control). This effect of intracellular treatment was observed in seven of the eleven treated cells. They further conducted experiments with dichlorodiaminocyclohexane platinum (Dach- $\mathrm{Cl}_{2}$-platin) and oxalate, which are the two major metabolites of oxaliplatin [36]. They found that oxalate, but not Dach- $\mathrm{Cl}_{2}$-platin, could decrease the maximum sodium current peak similarly to oxaliplatin. When $500 \mu \mathrm{M}$ of oxalate was administered intracellularly, the sodium current decreased by $36 \pm 2 \%$ of the control. These results suggested that oxalate may play an important role in the effect of oxaliplatin. In accordance with previously reported results, Benoit et al. [34] showed that the peak sodium current consistently decreased to $77 \pm 8 \%$ and $41 \pm 7 \%$ of its control value after $10 \mu \mathrm{M}$ and $100 \mu \mathrm{M}$ oxaliplatin application, respectively.

\subsection{Oxaliplatin Shifts the Voltage-Response Relationship of the Sodium Current}

Adelsberger et al. [31] reported that $250 \mu \mathrm{M}$ of oxaliplatin shifted the voltage-response relationship of $10 \mathrm{mV}$ toward more negative potentials. Benoit et al. [34] reported that oxaliplatin shifted the peak sodium current voltage curves toward negative membrane potentials, showing that oxaliplatin induces current activation at a more negative potentials. Under the chemotherapeutic agent, the sodium current started to be activated at $-50 \mathrm{mV}$ with 10 or $100 \mu \mathrm{M}$, whereas no current was active under control conditions.

\subsection{Oxaliplatin Slowdown Inactivation Kinetics of Voltage-Gated Sodium Channels}

On the effect of oxaliplatin on the inactivation kinetics, there is conflicting evidence that whether oxaliplatin induces a slowdown of the inactivation current. First, Adelsberger et al. [31] reported that the slowdown of the inactivation kinetics of the channel occurred after oxaliplatin injection, and that this slowdown of the inactivation sodium current resulted in an increase in the total current by $2.6 \pm 1.45 \%$. This effect could be observed only in the DRG and not in the hippocampal neurons, suggesting that oxaliplatin preferentially acts on certain types of voltage-gated sodium channel isoforms expressed 
mainly in the peripheral nervous system. Sittl et al. [32] also demonstrated that oxaliplatin significantly induced slow inactivation at a negative potential in isolation in neuron-derived ND7/23 cells transfected with the murine $\mathrm{Na}_{\mathrm{v}} 1.6 \mathrm{r}$ and auxiliary $\beta 4$-subunit. The slowing inactivation at a negative membrane potential prolonged $\mathrm{Na}_{\mathrm{v}}$ open times and increased resurgent and persistent current in native DRG neurons. However, in experiments conducted on frog myelinated neurons, Benoit et al. [34] reported that oxaliplatin did not induce slow down inactivation of the sodium current. This discrepancy may be due to the difference in the animals used (rat DRG and cockroach DUM neurons vs. frog sciatic nerve).

\section{Effect of Oxaliplatin on TTX-Sensitive or Resistant Sodium Channels}

\subsection{Oxaliplatin Modulates the Activity of TTX-Sensitive Sodium Channels}

DRG neurons express different types of voltage-gated sodium channel isoforms: TTX-resistant isoforms $\mathrm{Na}_{\mathrm{v}} 1.8$ and $\mathrm{Na}_{\mathrm{v}}$ 1.9, and TTX-sensitive isoforms $\mathrm{Na}_{\mathrm{v}} 1.1, \mathrm{Na}_{\mathrm{v}} 1.2, \mathrm{Na}_{\mathrm{v}}$ 1.3, $\mathrm{Na}_{\mathrm{v}}$ 1.6, and $\mathrm{Na}_{\mathrm{v}} 1.7$ [37]. To investigate whether oxaliplatin affects TTX-sensitive or TTX-resistant voltage-gated sodium channels, Webster et al. [29] evoked potential in the phrenic nerve hemidiaphragm and vas deferens to evaluate the effect of oxaliplatin on both the motor nerve function and autonomic system. They demonstrated that more than $30 \mathrm{~min}$ of $0.5 \mathrm{mM}$ of oxaliplatin application induced increased endplate potential (EPP), miniature endplate potentials (MEPPs), and frequency of spontaneous excitatory junction potential (sEJP). However, these effects were all blocked by $1 \mu \mathrm{M}$ of TTX, showing that oxaliplatin modifies the activity of TTX-sensitive voltage-gated sodium channels. Furthermore, in accordance with the data of Adelsberger et al. [31], $0.3 \mathrm{mM}$ of sodium channel blocker, carbamazepine, also prevented the multiple EPPs and increased spontaneous activities.

\subsection{Effect of Oxaliplatin on $N a_{v} 1.6$}

$\mathrm{Na}_{\mathrm{v}} 1.6$ is a TTX-sensitive voltage-gated sodium channel expressed in various types of neuronal cells. Studies have shown evidence that $\mathrm{Na}_{\mathrm{v}} 1.6$ is expressed both in the central and peripheral nervous system, but mostly on myelinated axons [25,38]. Sittl et al. [32] reported that after potentials induced by oxaliplatin were completely absent in $\mathrm{Na}_{\mathrm{v}} 1.6$ knockout mice, but not in heterozygous mice. Moreover, by using $\mathrm{Na}_{\mathrm{v}} 1.6$ deficient mice ( $\mathrm{Scn} 8 \mathrm{a}^{\mathrm{med} / \mathrm{med}}$ ), they showed that cooling the media to $20{ }^{\circ} \mathrm{C}$ induced stimulus evoked action potential bursts in single axons, whereas these action potentials could not be observed on physiological skin temperature (i.e., 30-32 ${ }^{\circ} \mathrm{C}$ ). As reported by Sittl et al. [32], Deuis et al. [39] also showed that $\mathrm{Na}_{\mathrm{v}} 1.6$ plays an important role in the activity of oxaliplatin. In their experiment, $\mathrm{Na}_{\mathrm{v}} 1.8^{-/-}$and $1.9^{-/-}$mice as well as $\mathrm{Na}_{\mathrm{v}} 1.8$-selective small-molecule inhibitor's application showed oxaliplatin-induced cold allodynia, suggesting that TTX-sensitive, but not resistant voltage-gated sodium channels play an important role in the development of allodynia. To prove this, they injected a low dose of TTX and demonstrated that TTX can indeed inhibit cold allodynia. Subsequently, to determine which TTX-sensitive sodium channel subtype plays a major role in the development of pain, they conducted experiments with $\mathrm{Na}_{\mathrm{v}} 1.3^{-/-}$and $\mathrm{Na}_{\mathrm{v}} 1.7,1.1,1.2$, and 1.4 subtype selective inhibitors (ProTxII and $\mu$-Conotoxin TIIIA, respectively), but none of these inhibitors affected the cold allodynia induced by oxaliplatin. However, intraplantar injection of $10 \mu \mathrm{M}$ GIIIA, which, in addition to Nav1.1, also inhibits Nav1.6 at high concentrations [40], achieved near-complete reversal of oxaliplatin-induced cold allodynia (14 $\pm 9 \%$ of control), demonstrating the functional contribution of Nav1.6 to cold pain pathways at the behavioral level. Li et al. [30] showed that following intraperitoneal oxaliplatin injection $\left(2.4,3.2\right.$, or $4.0 \mathrm{mg} / \mathrm{kg}$ twice weekly for 4.5 weeks), expression levels of $\mathrm{Na}_{\mathrm{v}} 1.6 \mathrm{mRNA}\left(F_{(3,15)}=60.98\right.$, $P<0.0001)$, and protein $\left(F_{(3,15)}=15.00, P=0.0002\right)$ were significantly increased compared to naïve rats. Moreover, the expression of $\mathrm{Na}_{\mathrm{v}} 1.6\left(F_{(3,11)}=18.67, P=0.0006\right.$, and $\left.F_{(3,11)}=52.54, P<0.0001\right)$ in the DRG was also markedly upregulated within each dose of oxaliplatin. Furthermore, immunofluorescent staining showed a significant increase in the ratio of $\mathrm{Na}_{\mathrm{v}}$ 1.6-positive DRG neurons in oxaliplatin-treated rats compared to control rats $(P<0.001)$. These results provide strong evidence indicating that oxaliplatin alters the expression of TTX-sensitive $\mathrm{Na}_{\mathrm{v}} 1.6$ in DRG neurons. 
Table 1. Summary table of studies on oxaliplatin and voltage-gated sodium channels.

\begin{tabular}{|c|c|c|c|c|c|c|}
\hline $\begin{array}{l}\text { Published } \\
\text { Year }\end{array}$ & Author & Models & & nvestigated Nerve & Oxaliplatin Doses & Discoveries \\
\hline 2000 & $\begin{array}{l}\text { Helmuth } \\
\text { Adelsberger } \\
\text { et al. [31] }\end{array}$ & Rat & $\begin{array}{l}(1) \\
(2) \\
(3)\end{array}$ & $\begin{array}{l}\text { Sural, peroneal and } \\
\text { vagal nerve } \\
\text { DRG } \\
\text { Hippocampal neurons }\end{array}$ & $250 \mu \mathrm{M}$ & $\begin{array}{l}\text { (1) Increase CAP amplitude in A- than C-fiber ( } 218 \pm 68 \% \text { vs. } \\
36 \pm 29 \%, n=7 \text { ) } \\
\text { (2) Shift of the voltage-response relationship to negative } \\
\text { potentials }(10 \mathrm{mV}, n=13 / 18) \\
\text { (3) Reduction of the maximal amplitude }(0.65 \pm 0.23, n=13) \\
\text { (4) Slowdown of the inactivation kinetics of the channels } \\
(2.6 \pm 1.45, n=13) \\
\text { (5) No effect on } \mathrm{Na}^{+} \text {current in hippocampal neurons }(n=8)\end{array}$ \\
\hline 2001 & $\begin{array}{c}\text { Francoise Grolleau } \\
\text { et al. [33] }\end{array}$ & $\begin{array}{c}\text { Cockroach } \\
\text { (Periplaneta americana) }\end{array}$ & & DUM neurons & $\begin{array}{c}100 \\
\text { And } \\
500 \mu \mathrm{M}\end{array}$ & $\begin{array}{l}\text { (1) Effect of extracellular and intracellular application on } \\
\text { maximum peak } \mathrm{Na}^{+} \text {currents }(100 \mu \mathrm{M}, 16.7 \pm 5.8 \% \mathrm{vs} \text {. } \\
52.8 \pm 3.3 \%, n=6 \text { and } 5 \text {, respectively) } \\
\text { (2) Maximum blocking effect of } \mathrm{Na}^{+} \text {currents }(1 \mathrm{mM} \text {, } \\
59.2 \pm 1.6 \%, n=3) \\
\text { (3) Dose dependent effect of oxalate }(1 \mathrm{mM}, 50.5 \pm 7.5 \%, n \\
=3) \\
\text { (4) } \begin{array}{l}\text { Reduction of both depolarizing phase and } \\
\text { posthyperpolarization associated with increase in } \mathrm{AC} \\
\text { duration }(500 \mu \mathrm{M})\end{array}\end{array}$ \\
\hline 2005 & $\begin{array}{l}\text { Richard G. } \\
\text { Webster } \\
\text { et al. [29] }\end{array}$ & $\begin{array}{c}\text { Mouse } \\
(\text { C57/BL6 and Balb/c) }\end{array}$ & $\begin{array}{l}(1) \\
(2)\end{array}$ & $\begin{array}{l}\text { Hemidiaphragm } \\
\text { (Phrenic nerve, } \\
\text { C57/BL6) } \\
\text { Vas deferens (Balb/c) }\end{array}$ & $500 \mu \mathrm{M}$ & $\begin{array}{l}\text { (1) Increased MEPP frequency in hemidiaphragm compared } \\
\text { to control }(0.5 \mathrm{mM}, 1.07 \pm 0.08 \mathrm{vs} .32 .10 \pm 7.49 \\
\text { respectively, } n=4) \\
\text { (2) Increase MEPP prevented by TTX pretreatment }(1 \mu \mathrm{M}) \\
\text { (3) Carbamazepine reduced MEPP and EPP amplitudes }(0.3 \\
\mathrm{mM}, 16.1 \% \text { and } 21.6 \% \text {, respectively, } n=4) \\
\text { (4) } \beta \text {-pompilidotoxin induced multiple EPPs }(0.1 \mathrm{mM}) \\
\text { (5) Frequency of sEJP increased }\left(0.5 \mathrm{mM}, 0.11 \pm 0.03 \mathrm{~s}^{-1} \mathrm{vs} \text {. }\right. \\
\left.0.042 \pm 0.015 \mathrm{~s}^{-1}, n_{p}=7\right) \\
\text { (6) TTX administration abolished all sEJPs }(100 \mathrm{nM}) \\
\text { (7) Carbamazepine reduced amplitude of EJPs }(0.3 \mathrm{mM}, \\
55 \pm 12 \%, n=5)\end{array}$ \\
\hline
\end{tabular}


Table 1. Cont.

\begin{tabular}{|c|c|c|c|c|c|c|c|}
\hline $\begin{array}{c}\text { Published } \\
\text { Year }\end{array}$ & Author & Models & & ivestigated Nerve & Oxaliplatin Doses & & Discoveries \\
\hline 2006 & $\begin{array}{l}\text { Evelyne Benoit } \\
\text { et al. [34] }\end{array}$ & $\begin{array}{c}\text { Frog } \\
\text { (Rana esculenta) }\end{array}$ & & $\begin{array}{l}\text { atic nerve (Nodes of } \\
\text { vier of single sensory } \\
\text { motor myelinated } \\
\quad \text { axon) }\end{array}$ & $\begin{array}{c}1 \\
10 \\
\text { And } \\
100 \mu \mathrm{M}\end{array}$ & $\begin{array}{l}\text { (2) } \\
\text { (3) }\end{array}$ & $\begin{array}{l}\text { Decreased nodal } \mathrm{Na}^{+} \text {currents peak after } 5-7 \mathrm{~min} \\
\text { application }(10 \text { and } 100 \mu \mathrm{M}, 77 \pm 8 \% \text { and } 41 \pm 7 \% \text { of its } \\
\text { control value, respectively, } n=10-11) \\
\text { Shift of } \mathrm{Na}^{+} \text {currents peak towards negative membrane } \\
\text { potentials }(1 \text { and } 100 \mu \mathrm{M},-3.5 \pm 0.5 \mathrm{mV} \text { and }-8.8 \pm 0.3 \\
\mathrm{mV} \text { compared to control, } n=3-4) \\
\text { A negative shift in the steady-state inactivation-voltage } \\
\text { curve of } \mathrm{Na}^{+} \text {currents peak }(1 \text { and } 100 \mu \mathrm{M}, 8.5 \pm 2.8 \mathrm{mV} \\
\text { and } 10 \pm 2.2 \mathrm{mV} \text { more negative compared to control, } n \\
=3-4)\end{array}$ \\
\hline 2012 & $\begin{array}{l}\text { Ruth Sittl } \\
\text { et al. [32] }\end{array}$ & $\begin{array}{c}\text { Human (Five male } \\
\text { patients } 57 \pm 9 \text { years of } \\
\text { age) } \\
\text { and Scn8amed Mice }\end{array}$ & & $\begin{array}{l}\text { Sural nerves } \\
\text { (CAP recording) } \\
\text { Saphenous nerve } \\
\text { (single-fiber recordings) }\end{array}$ & $\begin{array}{c}10 \\
\text { And } \\
100 \mu \mathrm{M}\end{array}$ & $\begin{array}{l}(2) \\
\text { (3) }\end{array}$ & $\begin{array}{l}\text { Cooling-induced CAP after potentials observed in A-, but } \\
\text { not C-fibers both in human and mice nerves }(100 \mu \mathrm{M} \text {, at } \\
20{ }^{\circ} \mathrm{C}, n=8 \text { and } 55 \text { for human and mouse respectively) } \\
\text { After potentials absent in nerves from Scn8a } 8 \text { med/med mice } \\
\text { Enhancement of } \mathrm{Na}_{\mathrm{v}} 1.6 \text {-mediated resurgent sodium } \\
\text { currents in myelinated DRG neurons (control } 22.2 \pm 3.4 \\
\mathrm{pA} / \mathrm{pF} \text { at } 30^{\circ} \mathrm{C} \text { vs. } 21.9 \pm 4.9 \text { at } 22^{\circ} \mathrm{C} \mathrm{pA} / \mathrm{pF}, n=5-8, P= \\
0.56 \text {; oxaliplatin, } 29.6 \pm 3.8 \mathrm{pA} / \mathrm{pF} \text { at } 30^{\circ} \mathrm{C} \text { vs. } 57.3 \pm 10.6 \\
\left.\text { pA/pF at } 22^{\circ} \mathrm{C}, n=5-11, P<0.05\right) . \\
\text { TTX-sensitive } \mathrm{Na}_{\mathrm{v}} \text { activation and steady-state fast } \\
\text { inactivation not affected }(n=4-10)\end{array}$ \\
\hline
\end{tabular}


Table 1. Cont

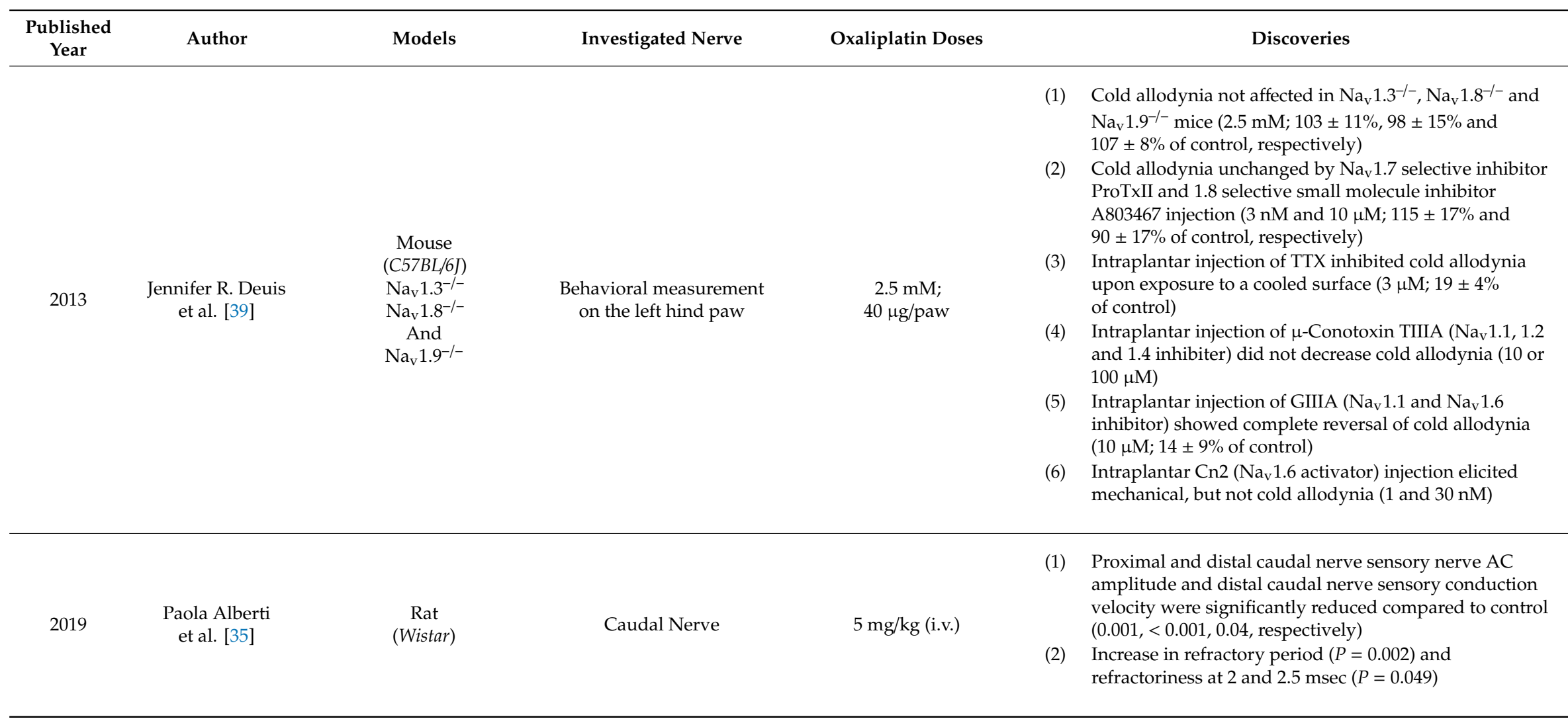


Table 1. Cont

\begin{tabular}{|c|c|c|c|c|c|c|}
\hline $\begin{array}{l}\text { Published } \\
\text { Year }\end{array}$ & Author & Models & Investigated Nerve & Oxaliplatin Doses & & Discoveries \\
\hline \multirow{5}{*}{2019} & \multirow{5}{*}{$\begin{array}{l}\text { Lei Li } \\
\text { et al. [30] }\end{array}$} & \multirow{5}{*}{ Rat (Sprague-Dawley) } & \multirow{5}{*}{ DRG (L4-6) } & \multirow{5}{*}{$\begin{array}{c}2.4 \\
3.2, \\
4.0 \mathrm{mg} / \mathrm{kg} \text { (i.p.) } \\
\text { And } \\
0.1 \mu \mathrm{M}\end{array}$} & (1) & $\begin{array}{l}\text { Intragastric administration of Bulleyaconitine A (a } \\
\text { sodium channel inhibitor) significantly attenuated } \\
\text { mechanical allodynia }\left(0.1 \mathrm{mg} / \mathrm{kg} ; F_{(2,66)}=218.92\right. \\
P<0.0001)\end{array}$ \\
\hline & & & & & $(2)$ & $\begin{array}{l}\text { The expression levels of } \mathrm{Na}_{\mathrm{v}} 1.6 \text { mRNA }\left(F_{(3,15)}=60.98,\right. \\
P<0.0001), \text { protein }\left(\mathrm{F}_{(3,15)}=15.00, P=0.0002\right) \text { and } \mathrm{Na}_{\mathrm{v}} 1.6 \\
\left(F_{(3,11)}=18.67, P=0.0006 \text { and } F_{(3,11)}=52.54, P<0.0001\right) \text { in } \\
\text { the DRG were significantly increased compared to control } \\
\text { (measured by RT-qPCR and immunofluorescent staining) }\end{array}$ \\
\hline & & & & & (3) & $\begin{array}{l}\text { Both } \operatorname{Scn} 8 a \text { mRNA }\left(F_{(4,14)}=26.95, P<0.0001\right) \text { and } \mathrm{Na}_{\mathrm{v}} 1.6 \\
\text { protein }\left(F_{(4,19)}=57.93, P<0.0001\right) \text { level increased, while } \\
\text { miR-30b }\left(F_{(4,14)}=14.60, P=0.0004\right) \text { decreased after dose } \\
\text { dependent administration of oxaliplatin }(0.1,0.2, \\
\text { and } 0.3 \mu \mathrm{M}) \text { into the culture medium }\end{array}$ \\
\hline & & & & & $(4)$ & $\begin{array}{l}\text { miR- } 30 \mathrm{~b} \text { agomir treatment markedly mitigated the } \\
\text { oxaliplatin induced increase in Scn8a mRNA and } \\
\mathrm{Na}_{\mathrm{v}} 1.6 \text { protein }\end{array}$ \\
\hline & & & & & $(5)$ & $\begin{array}{l}\text { Intrathecal administration of the miR-30b agomir } \\
\text { inhibited the expression of } \mathrm{Na}_{\mathrm{V}} 1.6 \text { in DRG neurons ( } \mathrm{F} \\
(3.11)=17.87, P=0.0007)\end{array}$ \\
\hline
\end{tabular}

Abbreviations: AC, Action Potential; CAP, Compound Action Potential; DRG, Dorsal Root Ganglia; DUM, Dorsal Unpaired Median; EJP, Excitatory Junction Potential; MEPP, Miniature Endplate Potential; I.P., Intraperitoneal; I.V., Intravenous; TTX, Tetrodotoxin. 


\section{Conclusions and Perspectives}

In this review, the effect of oxaliplatin on voltage-gated sodium channels was observed based on the results obtained from eight studies. Oxaliplatin was shown to affect myelinated A-fibers more compared to unmyelinated C-fibers, as CAP induced in C-fiber did not change following oxaliplatin injection [31,32]. Although in these studies, the subtypes of A-fibers affected by oxaliplatin were not mentioned, it has been reported that $\mathrm{A} \delta$-fibers are affected by oxaliplatin [41]. A $\delta$-fibers, which are sensory myelinated fibers with the thinnest myelin sheaths, are related to paresthesias (tickling or tingling sensations in the skin, whether distal or perioral), which is one of the most frequent symptoms of oxaliplatin-treated patients [42]. In addition, by using quantitative sensory testing, it was reported that cold pain are served by A $\delta$-fibers [43], and a clinical study demonstrated that blockade of A-fibers reduced the cold hyperalgesia in oxaliplatin treated patients [44].

In addition, two studies reported that oxaliplatin increased the duration of the action potential [31,33], while other data showed that the duration of the action potential was reduced [34]. However, as mentioned above, these discrepancies may result from differences in the animals (rat DRG and cockroach DUM neurons vs. frog sciatic nerve) or the doses used ( 250 and $500 \mu \mathrm{M}$ vs. 10 and $100 \mu \mathrm{M})$. In contrast, three studies concur that oxaliplatin decreased the peak of the sodium current $[31,33,34]$, as also reported in a clinical trial [45]. In this review, the precise mechanism has not been mentioned; however, Benoit et al. [34] and Grolleau et al. [33] mentioned that oxalate, which is a major metabolite of oxaliplatin, may act as a calcium ion chelator, blocking the voltage-gated sodium channel by controlling the external surface membrane potentials $[33,34,46]$.

The importance of calcium ions in oxaliplatin-induced allodynia was reported in several articles $[47,48]$, and some clinical studies have recommended calcium and magnesium infusion to prevent oxaliplatin-induce neuropathic pain [49,50]. Indeed, in the experiments of Deuis et al. [39], intraplantar injection of BAPTA (1,2-bis(o-aminophenoxy)ethane- $N, N, N^{\prime}, N^{\prime}$-tetraacetic acid), which is a calcium ion chelator, mimicked the allodynia induced by oxaliplatin, showing that removal of the extracellular calcium ion plays an important role in neuropathic pain. BAPTA injection decreased the threshold potential and membrane resistance, producing effects on inward sodium currents. As a divalent cation, calcium ion is able to modify the properties of the voltage-gated sodium channel by hyperpolarizing the cell membrane; thus, increased extracellular calcium ion concentration may induce sodium channel closing and reduce the effect of oxaliplatin on the activity of sodium channels.

Most studies included in the review reported that oxaliplatin acts on the TTX-sensitive pathway [29,32,39]. DRG neurons express several voltage-gated sodium channel isoforms, including the TTX-resistant isoforms $\mathrm{Na}_{\mathrm{v}} 1.8$ and $\mathrm{Na}_{\mathrm{v}} 1.9$, and the TTX-sensitive isoforms $\mathrm{Na}_{\mathrm{v}} 1.1, \mathrm{Na}_{\mathrm{v}} 1.2, \mathrm{Na}_{\mathrm{v}} 1.3$, $\mathrm{Na}_{\mathrm{v}} 1.6$, and $\mathrm{Na}_{\mathrm{v}} 1.7$ [37]. In the experiments of Deuis et al. [39], neither TTX-resistant sodium channel knockout mice nor inhibitor injection altered the pain induced by oxaliplatin, and among the various subtypes of TTX-resistant sodium channel, $\mathrm{Na}_{\mathrm{v}} 1.6$ was shown to be the most affected by oxaliplatin, as inhibition of this channel led to attenuation of cold allodynia. Voltage-gated sodium channels play a central role in the development of pain, as they are important for the initial transduction of sensory stimuli, the electrogenesis of the action potential, and neurotransmitter release from sensory neuron terminals [51]. Clinical trials have reported that carbamazepine, an anticonvulsant and a voltage-dependent sodium channel blocker, could attenuate oxaliplatin-induced neuropathic pain $[27,52,53]$. Duloxetine, a well-established anticonvulsants and analgesic drug, is recommended by the American Society of Clinical Organization (ASCO) guidelines [54] and the Journal of the American Medical Association (JAMA) [55] to prevent neuropathic pain induced by oxaliplatin. Duloxetine is a serotonin and norepinephrine reuptake inhibitor (SNRI); however, in addition to potentiation of serotonergic and noradrenergic activity in the central nervous system, duloxetine has been shown to be able to block neuronal sodium ion currents for its efficacy in neuropathic pain $[56,57]$. These studies show that duloxetine may decrease oxaliplatin-induced pain by modulating voltage-gated sodium channels. 
In this review, only the effects of oxaliplatin on voltage-gated sodium channels have been noted. However, for a better understanding of the mechanism, the simultaneous effects of oxaliplatin and its metabolites on voltage-gated sodium channels and other ion channels, such as potassium and calcium ion channels, should be investigated. Furthermore, the effects of these ion channel blockers' co-administration should also be evaluated, as the activities of these ion channels are closely related to each other.

Funding: This work was supported by a grant from Kyung Hee University in 2018 (KHU-20181294).

Conflicts of Interest: The authors declare no conflict of interest.

\section{References}

1. Misset, J.L.; Bleiberg, H.; Sutherland, W.; Bekradda, M.; Cvitkovic, E. Oxaliplatin clinical activity: A review. Crit. Rev. Oncol. Hematol. 2000, 35, 75-93. [CrossRef]

2. Argyriou, A.A.; Polychronopoulos, P.; Iconomou, G.; Chroni, E.; Kalofonos, H.P. A review on oxaliplatin-induced peripheral nerve damage. Cancer Treat. Rev. 2008, 34, 368-377. [CrossRef] [PubMed]

3. Nativi, C.; Gualdani, R.; Dragoni, E.; Mannelli, L.D.C.; Sostegni, S.; Norcini, M.; Gabrielli, G.; La Marca, G.; Richichi, B.; Francesconi, O. A trpa1 antagonist reverts oxaliplatin-induced neuropathic pain. Sci. Rep. 2013, 3, 2005. [CrossRef] [PubMed]

4. Nassini, R.; Gees, M.; Harrison, S.; De Siena, G.; Materazzi, S.; Moretto, N.; Failli, P.; Preti, D.; Marchetti, N.; Cavazzini, A. Oxaliplatin elicits mechanical and cold allodynia in rodents via trpa1 receptor stimulation. Pain ${ }^{\circledR}$ 2011, 152, 1621-1631. [CrossRef] [PubMed]

5. Zhao, M.; Isami, K.; Nakamura, S.; Shirakawa, H.; Nakagawa, T.; Kaneko, S. Acute cold hypersensitivity characteristically induced by oxaliplatin is caused by the enhanced responsiveness of trpa1 in mice. Mol. Pain 2012, 8, 55. [CrossRef]

6. Descoeur, J.; Pereira, V.; Pizzoccaro, A.; Francois, A.; Ling, B.; Maffre, V.; Couette, B.; Busserolles, J.; Courteix, C.; Noel, J. Oxaliplatin-induced cold hypersensitivity is due to remodelling of ion channel expression in nociceptors. EMBO Mol. Med. 2011, 3, 266-278. [CrossRef]

7. Kawashiri, T.; Egashira, N.; Kurobe, K.; Tsutsumi, K.; Yamashita, Y.; Ushio, S.; Yano, T.; Oishi, R. L type ca2+ channel blockers prevent oxaliplatin-induced cold hyperalgesia and trpm8 overexpression in rats. Mol. Pain 2012, 8, 7. [CrossRef]

8. Yoon, S.-Y.; Robinson, C.R.; Zhang, H.; Dougherty, P.M. Spinal astrocyte gap junctions contribute to oxaliplatin-induced mechanical hypersensitivity. J. Pain 2013, 14, 205-214. [CrossRef]

9. Janes, K.; Wahlman, C.; Little, J.W.; Doyle, T.; Tosh, D.K.; Jacobson, K.A.; Salvemini, D. Spinal neuroimmune activation is independent of $\mathrm{t}$-cell infiltration and attenuated by a3 adenosine receptor agonists in a model of oxaliplatin-induced peripheral neuropathy. Brain Behav. Immun. 2015, 44, 91-99. [CrossRef]

10. Xiao, W.H.; Bennett, G.J. Effects of mitochondrial poisons on the neuropathic pain produced by the chemotherapeutic agents, paclitaxel and oxaliplatin. Pain 2012, 153, 704-709. [CrossRef]

11. Riva, B.; Dionisi, M.; Potenzieri, A.; Chiorazzi, A.; Cordero-Sanchez, C.; Rigolio, R.; Carozzi, V.A.; Lim, D.; Cavaletti, G.; Marmiroli, P. Oxaliplatin induces ph acidification in dorsal root ganglia neurons. Sci. Rep. 2018, 8, 1-12. [CrossRef] [PubMed]

12. Krishnan, A.V.; Goldstein, D.; Friedlander, M.; Kiernan, M.C. Oxaliplatin-induced neurotoxicity and the development of neuropathy. Muscle Nerve Off. J. Am. Assoc. Electrodiagn. Med. 2005, 32, 51-60. [CrossRef] [PubMed]

13. Kim, W.; Kim, M.J.; Go, D.; Min, B.-I.; Na, H.S.; Kim, S.K. Combined effects of bee venom acupuncture and morphine on oxaliplatin-induced neuropathic pain in mice. Toxins 2016, 8, 33. [CrossRef] [PubMed]

14. Ling, B.; Authier, N.; Balayssac, D.; Eschalier, A.; Coudore, F. Behavioral and pharmacological description of oxaliplatin-induced painful neuropathy in rat. Pain 2007, 128, 225-234. [CrossRef]

15. Kim, W.; Chung, Y.; Choi, S.; Min, B.-I.; Kim, S.K. Duloxetine protects against oxaliplatin-induced neuropathic pain and spinal neuron hyperexcitability in rodents. Int. J. Mol. Sci. 2017, 18, 2626. [CrossRef]

16. Chae, H.K.; Kim, W.; Kim, S.K. Phytochemicals of cinnamomi cortex: Cinnamic acid, but not cinnamaldehyde, attenuates oxaliplatin-induced cold and mechanical hypersensitivity in rats. Nutrients 2019, 11, 432. [CrossRef] 
17. Lee, J.H.; Go, D.; Kim, W.; Lee, G.; Bae, H.; Quan, F.S.; Kim, S.K. Involvement of spinal muscarinic and serotonergic receptors in the anti-allodynic effect of electroacupuncture in rats with oxaliplatin-induced neuropathic pain. Korean J. Physiol. Pharmacol. 2016, 20, 407-414. [CrossRef]

18. Choi, S.; Chae, H.K.; Heo, H.; Hahm, D.-H.; Kim, W.; Kim, S.K. Analgesic effect of melittin on oxaliplatin-induced peripheral neuropathy in rats. Toxins 2019, 11, 396. [CrossRef]

19. Li, D.; Kim, W.; Shin, D.; Jung, Y.; Bae, H.; Kim, S.K. Preventive effects of bee venom derived phospholipase a2 on oxaliplatin-induced neuropathic pain in mice. Toxins 2016, 8, 27. [CrossRef]

20. Zain, M.; Bonin, R.P. Alterations in evoked and spontaneous activity of dorsal horn wide dynamic range neurons in pathological pain: A systematic review and analysis. Pain 2019, 160, 2199-2209. [CrossRef]

21. Jamieson, S.; Liu, J.; Connor, B.; McKeage, M. Oxaliplatin causes selective atrophy of a subpopulation of dorsal root ganglion neurons without inducing cell loss. Cancer Chemother. Pharmacol. 2005, 56, 391-399. [CrossRef] [PubMed]

22. Hains, B.C.; Saab, C.Y.; Waxman, S.G. Changes in electrophysiological properties and sodium channel nav1. 3 expression in thalamic neurons after spinal cord injury. Brain 2005, 128, 2359-2371. [CrossRef] [PubMed]

23. Park, S.; Krishnan, A.; Lin, C.; Goldstein, D.; Friedlander, M.; Kiernan, M. Mechanisms underlying chemotherapy-induced neurotoxicity and the potential for neuroprotective strategies. Curr. Med. Chem. 2008, 15, 3081-3094. [CrossRef] [PubMed]

24. Kagiava, A.; Tsingotjidou, A.; Emmanouilides, C.; Theophilidis, G. The effects of oxaliplatin, an anticancer drug, on potassium channels of the peripheral myelinated nerve fibres of the adult rat. Neurotoxicology 2008, 29, 1100-1106. [CrossRef] [PubMed]

25. Cummins, T.R.; Sheets, P.L.; Waxman, S.G. The roles of sodium channels in nociception: Implications for mechanisms of pain. Pain 2007, 131, 243-257. [CrossRef]

26. Rogers, M.; Tang, L.; Madge, D.J.; Stevens, E.B. The role of sodium channels in neuropathic pain. In Seminars in Cell \& Developmental Biology; Elsevier: Amsterdam, The Netherlands, 2006; pp. 571-581.

27. Eckel, F.; Schmelz, R.; Adelsberger, H.; Erdmann, J.; Quasthoff, S.; Lersch, C. Prevention of oxaliplatin-induced neuropathy by carbamazepine. A pilot study. Deutsche Medizinische Wochenschrift 1946 2002, 127, 78-82. [CrossRef]

28. Gamelin, E.; Gamelin, L.; Bossi, L.; Quasthoff, S. Clinical aspects and molecular basis of oxaliplatin neurotoxicity: Current management and development of preventive measures. Semin. Oncol. 2002, 29 (Suppl. 15), 21-33. [CrossRef]

29. Webster, R.G.; Brain, K.L.; Wilson, R.H.; Grem, J.L.; Vincent, A. Oxaliplatin induces hyperexcitability at motor and autonomic neuromuscular junctions through effects on voltage-gated sodium channels. Br. J. Pharmacol. 2005, 146, 1027-1039. [CrossRef]

30. Li, L.; Shao, J.; Wang, J.; Liu, Y.; Zhang, Y.; Zhang, M.; Zhang, J.; Ren, X.; Su, S.; Li, Y. Mir-30b-5p attenuates oxaliplatin-induced peripheral neuropathic pain through the voltage-gated sodium channel nav1. 6 in rats. Neuropharmacology 2019, 153, 111-120. [CrossRef]

31. Adelsberger, H.; Quasthoff, S.; Grosskreutz, J.; Lepier, A.; Eckel, F.; Lersch, C. The chemotherapeutic oxaliplatin alters voltage-gated na+ channel kinetics on rat sensory neurons. Eur. J. Pharmacol. 2000, 406, 25-32. [CrossRef]

32. Sittl, R.; Lampert, A.; Huth, T.; Schuy, E.T.; Link, A.S.; Fleckenstein, J.; Alzheimer, C.; Grafe, P.; Carr, R.W. Anticancer drug oxaliplatin induces acute cooling-aggravated neuropathy via sodium channel subtype nav1. 6-resurgent and persistent current. Proc. Natl. Acad. Sci. USA 2012, 109, 6704-6709. [CrossRef]

33. Grolleau, F.; Gamelin, L.; Boisdron-Celle, M.; Lapied, B.; Pelhate, M.; Gamelin, E. A possible explanation for a neurotoxic effect of the anticancer agent oxaliplatin on neuronal voltage-gated sodium channels. J. Neurophysiol. 2001, 85, 2293-2297. [CrossRef] [PubMed]

34. Benoit, E.; Brienza, S.; Dubois, J. Oxaliplatin, an anticancer agent that affects both $\mathrm{Na}^{+}$and $\mathrm{K}^{+}$channels in frog peripheral myelinated axons. Gen. Physiol. Biophys. 2006, 25, 263. [PubMed]

35. Alberti, P.; Canta, A.; Chiorazzi, A.; Fumagalli, G.; Meregalli, C.; Monza, L.; Pozzi, E.; Ballarini, E.; Rodriguez-Menendez, V.; Oggioni, N. Topiramate prevents oxaliplatin-related axonal hyperexcitability and oxaliplatin induced peripheral neurotoxicity. Neuropharmacology 2020, 164, 107905. [CrossRef] [PubMed]

36. Mauldin, S.K.; Gibbons, G.; Wyrick, S.D.; Chaney, S.G. Intracellular biotransformation of platinum compounds with the 1, 2-diaminocyclohexane carrier ligand in the 11210 cell line. Cancer Res. 1988, 48, 5136-5144. [PubMed] 
37. Rush, A.M.; Cummins, T.R.; Waxman, S.G. Multiple sodium channels and their roles in electrogenesis within dorsal root ganglion neurons. J. Physiol. 2007, 579, 1-14. [CrossRef]

38. Caldwell, J.H.; Schaller, K.L.; Lasher, R.S.; Peles, E.; Levinson, S.R. Sodium channel nav1. 6 is localized at nodes of ranvier, dendrites, and synapses. Proc. Natl. Acad. Sci. USA 2000, 97, 5616-5620. [CrossRef]

39. Deuis, J.R.; Zimmermann, K.; Romanovsky, A.A.; Possani, L.D.; Cabot, P.J.; Lewis, R.J.; Vetter, I. An animal model of oxaliplatin-induced cold allodynia reveals a crucial role for nav1. 6 in peripheral pain pathways. Pain $^{\circledR}$ 2013, 154, 1749-1757. [CrossRef]

40. Wilson, M.J.; Yoshikami, D.; Azam, L.; Gajewiak, J.; Olivera, B.M.; Bulaj, G.; Zhang, M.-M. M-conotoxins that differentially block sodium channels nav1. 1 through 1.8 identify those responsible for action potentials in sciatic nerve. Proc. Natl. Acad. Sci. USA 2011, 108, 10302-10307. [CrossRef]

41. Zedan, A.H.; Hansen, T.F.; Svenningsen, Å.F.; Vilholm, O.J. Oxaliplatin-induced neuropathy in colorectal cancer: Many questions with few answers. Clin. Colorectal Cancer 2014, 13, 73-80. [CrossRef] [PubMed]

42. Heide, R.; Bostock, H.; Ventzel, L.; Grafe, P.; Bergmans, J.; Fuglsang-Frederiksen, A.; Finnerup, N.B.; Tankisi, H. Axonal excitability changes and acute symptoms of oxaliplatin treatment: In vivo evidence for slowed sodium channel inactivation. Clin. Neurophysiol. 2018, 129, 694-706. [CrossRef]

43. Horowitz, S.H. The diagnostic workup of patients with neuropathic pain. Anesthesiol. Clin. 2007, 25, 699-708. [CrossRef] [PubMed]

44. Forstenpointner, J.; Oberlojer, V.C.; Naleschinski, D.; Höper, J.; Helfert, S.M.; Binder, A.; Gierthmühlen, J.; Baron, R. A-fibers mediate cold hyperalgesia in patients with oxaliplatin-induced neuropathy. Pain Pract. 2018, 18, 758-767. [CrossRef] [PubMed]

45. Krishnan, A.V.; Goldstein, D.; Friedlander, M.; Kiernan, M.C. Oxaliplatin and axonal na+ channel function in vivo. Clin. Cancer Res. 2006, 12, 4481-4484. [CrossRef] [PubMed]

46. Hille, B. Charges and potentials at the nerve surface: Divalent ions and ph. J. Gen. Physiol. 1968, 51, $221-236$. [CrossRef] [PubMed]

47. Schmitt, L.-I.; Leo, M.; Kleinschnitz, C.; Hagenacker, T. Oxaliplatin modulates the characteristics of voltage-gated calcium channels and action potentials in small dorsal root ganglion neurons of rats. Mol. Neurobiol. 2018, 55, 8842-8855. [CrossRef]

48. Yamamoto, K.; Tsuboi, M.; Kambe, T.; Abe, K.; Nakatani, Y.; Kawakami, K.; Utsunomiya, I.; Taguchi, K. Oxaliplatin administration increases expression of the voltage-dependent calcium channel $\alpha 2 \delta-1$ subunit in the rat spinal cord. J. Pharmacol. Sci. 2016, 130, 117-122. [CrossRef]

49. Gamelin, L.; Boisdron-Celle, M.; Delva, R.; Guérin-Meyer, V.; Ifrah, N.; Morel, A.; Gamelin, E. Prevention of oxaliplatin-related neurotoxicity by calcium and magnesium infusions: A retrospective study of 161 patients receiving oxaliplatin combined with 5-fluorouracil and leucovorin for advanced colorectal cancer. Clin. Cancer Res. 2004, 10, 4055-4061. [CrossRef]

50. Grothey, A.; Nikcevich, D.A.; Sloan, J.A.; Kugler, J.W.; Silberstein, P.T.; Dentchev, T.; Wender, D.B.; Novotny, P.J.; Chitaley, U.; Alberts, S.R. Intravenous calcium and magnesium for oxaliplatin-induced sensory neurotoxicity in adjuvant colon cancer: Ncctg n04c7. J. Clin. Oncol. 2011, 29, 421. [CrossRef]

51. Bennett, D.L.; Clark, A.J.; Huang, J.; Waxman, S.G.; Dib-Hajj, S.D. The role of voltage-gated sodium channels in pain signaling. Physiol. Rev. 2019, 99, 1079-1151. [CrossRef]

52. Lersch, C.; Schmelz, R.; Eckel, F.; Erdmann, J.; Mayr, M.; Schulte-Frohlinde, E.; Quasthoff, S.; Grosskreutz, J.; Adelsberger, H. Prevention of oxaliplatin-induced peripheral sensory neuropathy by carbamazepine in patients with advanced colorectal cancer. Clin. Colorectal Cancer 2002, 2, 54-58. [CrossRef]

53. Hoffman, K. Potential prevention and treatment of oxaliplatin associated peripheral neuropathy. J. Clin. Oncol. 2004, 22, 8093. [CrossRef]

54. Hershman, D.L.; Lacchetti, C.; Dworkin, R.H.; Smith, E.M.L.; Bleeker, J.; Cavaletti, G.; Chauhan, C.; Gavin, P.; Lavino, A.; Lustberg, M.B.; et al. Prevention and management of chemotherapy-induced peripheral neuropathy in survivors of adult cancers: American society of clinical oncology clinical practice guideline. J. Clin. Oncol. 2014, 32, 1941-1967. [CrossRef] [PubMed]

55. Smith, E.M.L.; Pang, H.; Cirrincione, C.; Fleishman, S.; Paskett, E.D.; Ahles, T.; Bressler, L.R.; Fadul, C.E.; Knox, C.; Le-Lindqwister, N. Effect of duloxetine on pain, function, and quality of life among patients with chemotherapy-induced painful peripheral neuropathy: A randomized clinical trial. Jama 2013, 309, 1359-1367. [CrossRef] [PubMed] 
56. Wang, S.-Y.; Calderon, J.; Wang, G.K. Block of neuronal na+ channels by antidepressant duloxetine in a state-dependent manner. Anesthesiol. J. Am. Soc. Anesthesiol. 2010, 113, 655-665. [CrossRef] [PubMed]

57. Rolland, J.-F.; Madge, D.; Ford, J.; Rogers, M. Biophysical characterization of duloxetine activity on voltage-gated sodium channels involved in pain transmission. Biophys. J. 2009, 96, 252a. [CrossRef]

(C) 2020 by the author. Licensee MDPI, Basel, Switzerland. This article is an open access article distributed under the terms and conditions of the Creative Commons Attribution (CC BY) license (http://creativecommons.org/licenses/by/4.0/). 